\title{
Chemotaxonomic patterns of vegetation and soils along altitudinal transects of the Bale Mountains, Ethiopia, and implications for paleovegetation reconstructions - Part II: lignin-derived phenols and leaf-wax-derived $n$-alkanes
}

\author{
Bruk Lemma $^{1,2}$, Betelhem Mekonnen ${ }^{1,3}$, Bruno Glaser ${ }^{1}$, Wolfgang Zech ${ }^{4}$, Sileshi Nemomissa ${ }^{5}$, Tamrat Bekele ${ }^{5}$, \\ Lucas Bittner $^{1}$, and Michael Zech ${ }^{1,6}$ \\ ${ }^{1}$ Institute of Agronomy and Nutritional Sciences, Soil Biogeochemistry, Martin Luther University Halle-Wittenberg, \\ Von-Seckendorff-Platz 3, 06120, Halle, Germany \\ ${ }^{2}$ Forest and Rangeland Biodiversity Directorate, Ethiopian Biodiversity Institute, P.O. Box 30726, Addis Ababa, Ethiopia \\ ${ }^{3}$ Department of Urban Agriculture, Misrak Polytechnic College, P.O. Box 785, Addis Ababa, Ethiopia \\ ${ }^{4}$ Institute of Soil Science and Soil Geography, University of Bayreuth, Universitätsstrasse 30, 95440, Bayreuth, Germany \\ ${ }^{5}$ Department of Plant Biology and Biodiversity Management, Addis Ababa University, P.O. Box 3434, Addis Ababa, Ethiopia \\ ${ }^{6}$ Institute of Geography, Technical University of Dresden, Helmholtzstrasse 10, 01062, Dresden, Germany
}

Correspondence: Bruk Lemma (bruklemma@gmail.com)

Relevant dates: $\quad$ Received: 9 August 2018 - Revised: 6 March 2019 - Accepted: 25 July 2019 Published: 4 September 2019

How to cite:

Lemma, B., Mekonnen, B., Glaser, B., Zech, W., Nemomissa, S., Bekele, T., Bittner, L., and Zech, M.: Chemotaxonomic patterns of vegetation and soils along altitudinal transects of the Bale Mountains, Ethiopia, and implications for paleovegetation reconstructions - Part II: lignin-derived phenols and leaf-wax-derived $n$-alkanes, E\&G Quaternary Sci. J., 68, 189-200, https://doi.org/10.5194/egqsj-68189-2019, 2019.

Abstract:

Erica is a dominant vegetation type in many sub-afroalpine ecosystems, such as the Bale Mountains in Ethiopia. However, the past extent of Erica is not well known and climate versus anthropogenic influence on altitudinal shifts are difficult to assign unambiguously, especially during the Holocene. The main objective of the present study is to chemotaxonomically characterize the dominant plant species occurring in the Bale Mountains using lignin phenols and $n$-alkane biomarkers and to examine the potential of those biomarkers for reconstructing vegetation history. Fresh plant material, organic layer and mineral topsoil samples were collected along a northeastern and a southwestern altitudinal transect (4134-3870 and 4377-2550 m a.s.l., respectively). Lignin-derived vanillyl, syringyl and cinnamyl phenols were analyzed using the cupric oxide oxidation method. Leaf-wax-derived $n$ alkanes were extracted and purified using Soxhlet and aminopropyl columns. Individual lignin phenols and $n$-alkanes were separated by gas-chromatography and detected by mass spectrometry and flame ionization detection, respectively.

We found that the relative contributions of vanillyl, syringyl and cinnamyl phenols allow us to chemotaxonomically distinguish contemporary plant species of the Bale Mountains. Erica in particular is characterized by relatively high cinnamyl contributions of $>40 \%$. However, litter degradation strongly decreases the lignin phenol concentrations and completely changes the lignin phenol pat- 
terns. Relative cinnamyl contributions in soils under Erica were $<40 \%$, while soils that developed under Poaceae (Festuca abyssinica) exhibited relative cinnamyl contributions of $>40 \%$.

Similarly, long-chain $n$-alkanes extracted from the leaf waxes allowed for differentiation between Erica versus Festuca abyssinica and Alchemilla, based on lower $\mathrm{C}_{31} / \mathrm{C}_{29}$ ratios in Erica. However, this characteristic plant pattern was also lost due to degradation in the respective $\mathrm{O}$ layers and $\mathrm{A}_{\mathrm{h}}$ horizons. In conclusion, although in modern-day plant samples a chemotaxonomic differentiation is possible, soil degradation processes seem to render the proxies unusable for the reconstruction of the past extent of Erica on the Sanetti Plateau, Bale Mountains, Ethiopia. This finding is of high relevance beyond our case study.

Kurzfassung: $\quad$ Erica prägt als dominante Pflanzengattung viele Subafro-alpine Ökosysteme, so auch die Bale Berge in Äthiopien. Das Ausmaß der flächenhaften Ausdehnung von Erica in der Vergangenheit ist jedoch unklar, genauso wie die klimatische versus menschliche Verursachung solcher Vegetationsänderungen insbesondere im Holozän. Das Ziel dieser Studie war es herauszufinden (i) ob sich die dominante Vegetation in den Bale Bergen anhand von ligninbürtigen Phenolen und blattwachsbürtigen $n$-Alkanbiomarkern chemotaxonomisch unterscheiden lässt und (ii) ob diese Biomarker das Potential haben zur Vegetationsrekonstruktion im Untersuchungsgebiet beizutragen. In einem Begleitartikel (Mekonnen et al., 2019) verfolgen wir dasselbe Ziel, jedoch anhand von Stabilkohlenstoff- und Stickstoffisotopen sowie Zuckerbiomarkern. Untersucht wurden Pflanzenproben, O-Lagen und $A_{h}$ Horizonte entlang eines Nord- und eines Südwest-Höhentransektes (3870-4134 m bzw. 2550-4377 m ü. NN). Die ligninbürtigen Phenoleinheiten Vannilly, Syringyl und Cinnamyl wurden mittels der Kupferoxidationsmethode gewonnen; die $n$-Alkane wurden mittels Soxhlet extrahiert und über Aminopropylsäulen aufgereinigt. Die Quantifizierung der Ligninphenole und $n$-Alkane erfolgte mittels Gaschromatographie - Massenspektrometrie bzw. Gaschromatographie - Flammenionisationsdetektion.

Die Ergebnisse zeigen, dass sich die dominanten Pflanzenarten in den Bale Bergen anhand ihrer Vanillyl, Syringyl und Cinnamyl Einheiten chemotaxonomisch unterscheiden lassen. So weist insbesondere Erica charakteristischerweise relativ hohe Cinnamyl-Anteile von $>40 \%$ auf. Vermutlich degradationsbedingt nimmt jedoch in der Reihe Pflanze - O-Lage $-\mathrm{A}_{\mathrm{h}}$ Horizont nicht nur die Ligninkonzentration stark ab, sondern auch die Ligninmuster ändern sich völlig. Dadurch weisen Böden unter Erica Cinnamyl-Anteile $<40 \%$ auf, während Böden die sich unter der dominanten Grasart Festuca abyssinica entwickelt haben Cinnamyl-Anteile von $>40 \%$ aufweisen. Auch anhand der Alkanbiomarker ist eine chemotaxonomische Unterscheidung zumindest zwischen Erica versus Festuca abyssinica und Alchemilla möglich. Als Proxy dient hier das Verhältnis von $\mathrm{C}_{31} \mathrm{zu}_{2} \mathrm{C}_{29}$. Allerdings führt auch hier Degradation in der Reihe Pflanze - O-Lage $-\mathrm{A}_{\mathrm{h}}$ Horizont zum Verlust des charakteristischen Alkanmusters. Obwohl sich rezentes Pflanzenmaterial chemotaxonomisch unterscheiden lässt, zwingt dies zur Schlussfolgerung, dass Degradationseffekte bei der Rekonstruktion von Erica im Untersuchungsgebiet der Bale Berge in Äthiopien anhand von ligninbürtigen Phenolen und blattwachsbürtigen Alkanbiomarkern nicht unberücksichtigt bleiben dürfen. Dieser Befund ist über unsere Fallstudie hinaus von hoher Relevanz.

\section{Introduction}

The Bale Mountains are an eastern afromontane biodiversity hotspot area with 27 endemic species of flowering plants (Hillman, 1988). Like in many other afromontane ecosystems, an altitudinal zonation of the vegetation is well established, with an Ericaceous belt forming a prominent feature. Ericaceous vegetation dominates above $3300 \mathrm{~m}$ a.s.l., shows different stages of post-fire succession and remains continuous up to $3800 \mathrm{~m}$ a.s.l. However, it becomes patchy on the Sanetti Plateau (Miehe and Miehe, 1994). The Bale Moun- tains National Park is increasingly under threat from climate change and anthropogenic impacts (Kidane et al., 2012). Ascertaining the past environmental and vegetation history of the area will support conservation efforts and may help to disentangle the influence of climate versus human impact on the present biodiversity.

Until now, the vegetation history of the Bale Mountains was studied using pollen records from lacustrine sediments and peat deposits (Bonnefille and Hamilton, 1986; Bonnefille and Mohammed, 1994; Hamilton, 1982; Umer et al., 2007). The results suggest the extension of the Ericaceous belt to- 
wards higher altitudes during the early and middle Holocene. As potential drawbacks, such pollen studies depend on pollen preservation and can be biased by variable pollination rates as well as middle- and long-distance pollen transport (Hicks, 2006; Jansen et al., 2010; Ortu et al., 2006). By contrast, stable isotopes and biomarkers can also be applied to more degraded sedimentary archives and soils and are assumed to reflect the standing vegetation more (Glaser and Zech, 2005). Thus, they offer the potential to complement pollen-based vegetation reconstructions and to reconstruct vegetation at a higher temporal and spatial resolution. For instance, the stable carbon isotopic composition $\left(\delta^{13} \mathrm{C}\right)$ of lacustrine sediments suggests an expansion of alpine $\mathrm{C}_{4}$ grasses on Mount Kenya, especially during glacial times (Street-Perrott et al., 2004), whereas $\delta^{13} \mathrm{C}$ results from (paleo-)soils provide no evidence for $\mathrm{C}_{4}$ grass expansion close to Mount Kilimanjaro during late Pleistocene glacial period (Zech, 2006; Zech et al., 2011b). We focus here on lignin-derived phenols and leaf-wax-derived $n$-alkanes as biomarkers, while stable isotopes and sugar biomarkers and their chemotaxonomic potential for reconstructions of the Bale Mountains vegetation are addressed in a companion paper by Mekonnen et al. (2019).

Lignin has a polyphenolic biochemical structure produced by terrestrial vascular plants (Ertel and Hedges, 1984) providing strength and rigidity to the plants (Thevenot et al., 2010). The lignin-derived phenols vanillyl (V), syringyl (S) and cinnamyl $(\mathrm{C})$ as products of cupric oxide $(\mathrm{CuO})$ oxidation are used to differentiate sources of organic matter and provide information about the diagenetic state (degree of degradation) of vascular plant material in terrestrial and aquatic sediments (Castañeda et al., 2009; Hedges et al., 1988; Tareq et al., 2004, 2006; Ziegler et al., 1986). For instance, low ratios of $\mathrm{S} / \mathrm{V} \sim 0$ were suggested as a proxy for the relative contribution of gymnosperms, and elevated $\mathrm{S} / \mathrm{V}$ ratios were found to be indicative for the presence of angiosperms (Tareq et al., 2004). Likewise, the C / V ratio was proposed to indicate the relative contribution of woody $(\mathrm{C} / \mathrm{V}<0.1)$ and non-woody $(\mathrm{C} / \mathrm{V}>0.1)$ plants to the soil and sediment organic matter (Tareq et al., 2011). Moreover, the ratios of acid to aldehyde forms of vanillyl and syringyl units $(\mathrm{Ac} / \mathrm{Al}) \mathrm{v}, \mathrm{s}$ were suggested as proxies for quantifying the degree of lignin degradation (Amelung et al., 2002; Hedges and Ertel, 1982; Möller et al., 2002).

$n$-alkanes are important constituents of plant leaf waxes (Kolattukudy, 1970), where they serve to protect plants against water loss by evaporation as well as from fungal and insect attacks (Eglinton and Hamilton, 1967; Koch et al., 2009). Due to their recalcitrant nature, they are often well preserved in sedimentary archives and used as biomarkers (also called molecular fossils) in paleoclimate and environmental studies (Eglinton and Eglinton, 2008; Glaser and Zech, 2005; Zech et al., 2011c). The potential of $n$-alkanes for chemotaxonomic studies has been suggested based on the finding that the homologues $\mathrm{C}_{27}$ and $\mathrm{C}_{29}$ are sourced pre- dominantly from trees and shrubs, whereas the homologues $\mathrm{C}_{31}$ and $\mathrm{C}_{33}$ are sourced predominantly from grasses and herbs (Maffei, 1996; Maffei et al., 2004; Rommerskirchen et al., 2006; Schäfer et al., 2016; Zech, 2009). Potential pitfalls when applying $n$-alkane proxies in paleovegetation studies should not be overlooked. For instance, (Bush and McInerney, 2013) caution against the chemotaxonomic application of $n$-alkanes because of high $n$-alkane pattern variability within graminoids and woody plants (Schäfer et al., 2016) emphasized the need for establishing regional calibration studies and Zech et al., (2011a, 2013) point to degradation affecting $n$-alkane proxies.

While the overall aim of our research is to contribute to the reconstruction of the paleoclimate and environmental history of the Bale Mountains, this study focuses more specifically on the following questions: (i) do lignin phenols and $n$ alkane biomarkers allow a chemotaxonomic differentiation of the dominant plant types of the Bale Mountains? (ii) Are the biomarker patterns of the plants reflected by and incorporated into the respective soils? (iii) Which implications have to be drawn from those results for planned paleovegetation reconstructions in the study area, e.g., concerning the reconstruction of the former extent of Erica? Finally, improved knowledge of the vegetation history of the Bale Mountains may help to support the biodiversity conservation program of the park in the face of future climate change and increasing human pressure.

\section{Material and methods}

\subsection{Study area and sample description}

The Bale Mountains are located $400 \mathrm{~km}$ southeast of Addis Ababa, the capital of Ethiopia (Hillman, 1986). Geographically, they belong to the Bale-Arsi massif, which forms the western section of the southeastern Ethiopian Highlands (Hillman, 1988; Miehe and Miehe, 1994; Tiercelin et al., 2008). The Bale Mountains National Park (BMNP) is situated at $39^{\circ} 28^{\prime}$ to $39^{\circ} 57^{\prime} \mathrm{E}$ and $6^{\circ} 29^{\prime}$ to $7^{\circ} 10^{\prime} \mathrm{N}$, (Hillman, 1988; Miehe and Miehe, 1994; Umer et al., 2007) with elevations ranging from 1400 to $4377 \mathrm{~m}$ a.s.l. The highest part forms the Sanetti Plateau, on which the second highest peak of the country, Mount Tullu Dimtu at $4377 \mathrm{~m}$ a.s.l. is also located (Hillman, 1988). The plateau is limited by the steep Harenna escarpment in the south and the southeast. The northeastern part is encompassed by high ridges and broad valleys that gradually descend towards the extensive Arsi-Bale plateaus and further into the Central Rift Valley lowlands (Hillman, 1988; Tiercelin et al., 2008). The topography of the Bale Mountains results in climatic gradients with respect to spatial and temporal distribution of rainfall as well as temperature (Tiercelin et al., 2008). Mean maximum temperature (MMT) on the mountain peaks ranges between 6 and $12^{\circ} \mathrm{C}$. At Dinsho (headquarters, $3170 \mathrm{~m}$ a.s.l.) the MMT is $11.8^{\circ} \mathrm{C}$. Mean mini- 


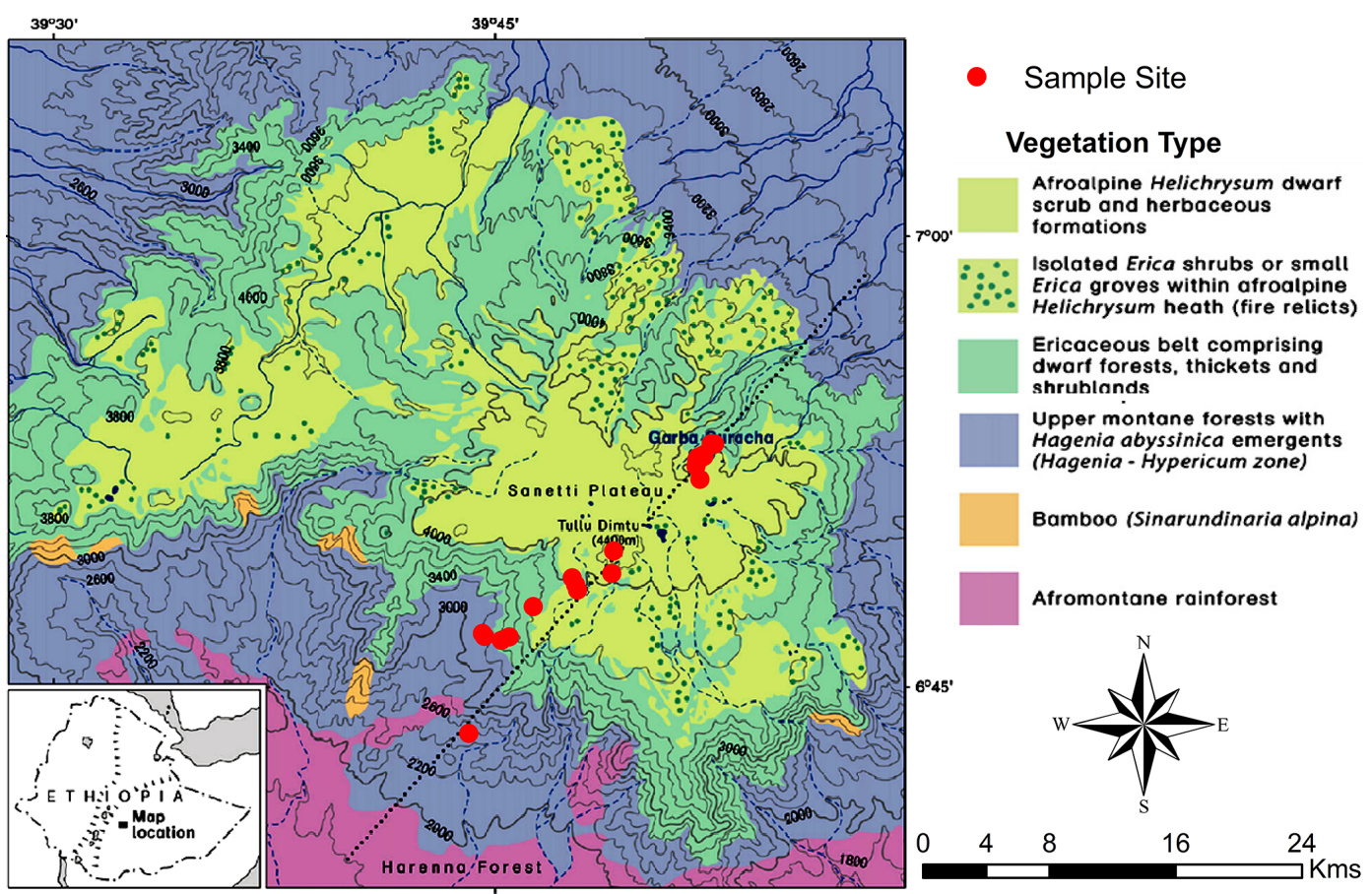

Figure 1. Map of the Bale Mountains for the vegetation zones and study sites along the northeastern and the southwestern transect (modified following Miehe and Miehe, 1994). Dominant vegetation types sampled that comprise the Ericaceous and afroalpine belt.

mum temperature ranges from 0.6 to $10^{\circ} \mathrm{C}$, with frequent frost occurring in the high peak areas during the winter season (Tiercelin et al., 2008). The highest annual rainfall and humidity occurs in the southwest part of the mountain with $1000-1500 \mathrm{~mm} \mathrm{yr}^{-1}$, and the northern part of the mountains exhibits annual rainfall ranging between 800 and $1000 \mathrm{~mm} \mathrm{yr}^{-1}$ (Woldu et al., 1989). The vegetation shows an altitudinal zonation comprised of the afromontane rainforest (1450-2000 ma.s.1.), the upper montane forests dominated by Hagenia and Hypericum species (2000-3200 m a.s.1.); the Ericaceous belt (3200-3800 m a.s.l.); and the afroalpine zone (3800-4377 m a.s.1.) dominated by dwarf shrubs such as $\mathrm{He}$ lichrysum, Alchemilla, herbs, and grasses (mostly Festuca; Fig. 1) (Friis, 1986; Miehe and Miehe, 1994). Geologically, the Bale Mountains consist of a highly elevated volcanic plateau dominated by alkali basalt, tuffs and rhyolite rocks. During the Last Glacial Maximum (LGM), it is understood that the regions of the high peak summits were glaciated and later flattened by repeated glaciations (Kidane et al., 2012; Osmaston et al., 2005; Umer et al., 2004). The soils having developed on the basaltic and trachyte rocks can be generally characterized as silt loam, having a reddish brown to black color (Woldu et al., 1989). They are usually shallow, gravelly and are assumed to have developed since the glacial retreat (Hedberg, 1964). Andosols are the most ubiquitous soil types. Nevertheless, Cambisols and Leptosols are also prevalent soil types in some parts of the Bale Mountains. In wetland and sedimentary basins, Gleysols and Histosols are also common (Billi, 2015; Yimer et al., 2006).

In February 2015, 25 leaf and twig samples of the dominant plant species were collected (Fig. 1) along a southwestern and a northeastern transect (ranging from 2550 to $4377 \mathrm{~m}$ a.s.l. and 3870 to $4134 \mathrm{~m}$ a.s.l., respectively). Samples comprised of Erica trimera (Engl.) Beentje $(n=5), E r$ ica arborea L. $(n=5)$, Alchemilla haumannii Rothm. $(n=$ 5), Festuca abyssinica Hochst. ex A. Rich. ( $n=6)$, Helichrysum splendidum Thunb. L. $(n=2)$, Kniphofia foliosa Hochst. $(n=1)$ and Lobelia rhynchopetalum Hemsl. $(n=1)$. Additionally, 15 organic surface layers $(=\mathrm{O}$ layers, strongly humified plant residues) and 22 mineral topsoils $\left(=A_{h}\right.$ horizons) that developed under the above listed dominant vegetation were collected from 27 sampling sites, resulting in 62 samples in total. For photos illustrating the investigated plant species and typical study sites, the reader is referred to Fig. 2 of our companion paper by Mekonnen et al. (2019). All samples were air-dried in the Soil Store Laboratory of the National Herbarium, Department of Plant Biology and Biodiversity Management, Addis Ababa University. In the laboratories of the Soil Biogeochemistry Group, Martin Luther University of Halle-Wittenberg, soil samples were sieved using a mesh size of $2 \mathrm{~mm}$, finely ground, homogenized and subjected to further biogeochemical analysis. 


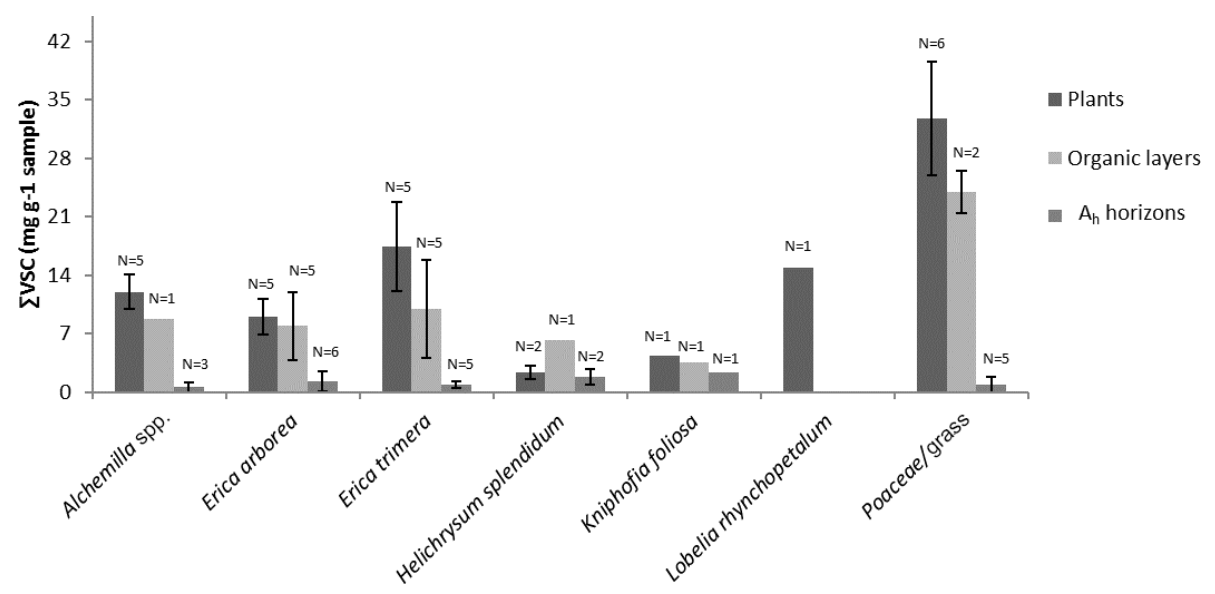

Figure 2. Sum of lignin phenol concentrations $\left(\sum \mathrm{VSC}\right)$ of contemporary plants, O layers and $\mathrm{A}_{\mathrm{h}}$ horizons. Error bars illustrate standard deviations.

\subsection{Analysis of lignin-derived phenol and leaf-wax-derived $n$-alkane biomarkers}

Lignin phenols were extracted from 35,50 and $500 \mathrm{mg}$ of plant, O-layer and $\mathrm{A}_{\mathrm{h}}$-horizon soil samples, respectively. The analytical procedure followed the cupric oxidation $(\mathrm{CuO})$ method developed by Hedges and Ertel (1982) and modified later on by Goñi and Hedges (1992). Briefly, the samples were transferred into Teflon digestion tubes together with $100 \mathrm{mg}$ of $\left(\mathrm{NH}_{4}\right)_{2} \mathrm{Fe}\left(\mathrm{SO}_{4}\right)_{2} \times 6 \mathrm{H}_{2} \mathrm{O}, 500 \mathrm{mg}$ of $\mathrm{CuO}, 50 \mathrm{mg}$ of $\mathrm{C}_{6} \mathrm{H}_{12} \mathrm{O}_{6}, 1 \mathrm{~mL}$ of ethylvanillin solution (100 ppm) as internal standard 1 (IS1) and $15 \mathrm{~mL}$ of $2 \mathrm{M} \mathrm{NaOH}$ and digested at $170{ }^{\circ} \mathrm{C}$ for $2 \mathrm{~h}$ under pressure. Reaction products were cooled overnight and transferred into centrifuge tubes. Then the phenolic compounds were purified by adsorption on $\mathrm{C}_{18}$ columns, desorbed by ethylacetate and concentrated under a stream of nitrogen gas for $30 \mathrm{~min}$. Residue was dissolved in $1 \mathrm{~mL}$ phenylacetic acid (PAA), a working internal standard stock solution to determine the recovery of ethylvanillin before derivatization (Amelung et al., 2002; Möller et al., 2002). Finally, the samples were derivatized using $200 \mu \mathrm{L}$ of N, O-bis(trimethylsilyl)trifluoroacetamide (BSTFA) and $100 \mu \mathrm{L}$ of pyridine. Oxidation products of lignin phenols were quantified using a SHIMADZU QP 2010 gas chromatography (GC) instrument coupled with a mass spectrometer (MS), (GCMS-QP2010, Kyoto, Japan).

After recovery correction, the concentration of each lignin phenol (in $\mathrm{mg} \mathrm{g}^{-1}$ ) was calculated from two or three $\mathrm{CuO}$ oxidation products according to the Eqs. (1), (2) and (3), respectively.

$$
\begin{aligned}
& \text { Vanillyl }(\mathrm{V})=\text { vanillin }+ \text { acetovanillone }+ \text { vanillic acid } \\
& \text { Syringyl }(\mathrm{S})=\text { syringaldehyde }+ \text { acetosyringone } \\
& + \text { syringic acid } \\
& \text { Cinnamyl }(\mathrm{C})=p \text {-coumaric acid }+ \text { ferulic acid }
\end{aligned}
$$

For data evaluation, the sum of $\mathrm{V}, \mathrm{S}$, and $\mathrm{C}\left(\sum \mathrm{VSC}\right)$; the ratios of $\mathrm{S} / \mathrm{V}$, and $\mathrm{C} / \mathrm{V}$; and the ratios of acids to aldehydes (Ac / Al) for the syringyl and vanillyl units were additionally calculated.

Leaf-wax-derived $n$-alkanes were extracted from 0.5 to $1 \mathrm{~g}$ of plant, O-layer and $\mathrm{A}_{\mathrm{h}}$-horizon soil samples using Soxhlet extraction by adding $150 \mathrm{~mL}$ of dichloromethane (DCM) and methanol $(\mathrm{MeOH})$ as solvents $(9: 1$ ratio) for $24 \mathrm{~h}$ following a method modified following Zech and Glaser (2008). In brief, $50 \mu \mathrm{L}$ of $5 \alpha$-androstane were added to the total lipid extracts (TLEs) as internal standard. TLEs were concentrated using rotary evaporation and transferred to aminopropyl columns. Three lipid fractions containing the $n$-alkanes, alcohols and fatty acids, respectively, were eluted successively by using $3 \mathrm{~mL}$ of hexane, DCM / MeOH $(1: 1)$, and diethyl ether and acetic acid $(95: 5)$ as eluent. The $n$-alkanes were separated on a gas chromatograph (GC) and detected by a flame ionization detector (FID), whereas the other two lipid fractions (alcohols and fatty acids) were archived. The GC instrument (GC-2010 SHMADZU) was equipped with a SPB5 column $(28.8 \mathrm{~m}$ length, $0.25 \mathrm{~mm}$ inner diameter, $0.25 \mu \mathrm{m}$ film thickness). The injector and detector temperature were 300 and $330^{\circ} \mathrm{C}$, respectively. The initial oven temperature was $90^{\circ} \mathrm{C}$. It is then raised in three ramps to $250^{\circ} \mathrm{C}$ at $20^{\circ} \mathrm{C} \mathrm{min}^{-1}$, further to $300^{\circ} \mathrm{C}$ at $2{ }^{\circ} \mathrm{C} \mathrm{min}^{-1}$ and finally to $320^{\circ} \mathrm{C}$ at $4^{\circ} \mathrm{C} \mathrm{min}^{-1}$, resulting in a total oven runtime of $50 \mathrm{~min}$. Helium (He) was used as carrier gas and $n$-alkane mixture $\left(\mathrm{C}_{8}-\mathrm{C}_{40}\right)$ was used as external standard for peak identification and quantification.

The total $n$-alkane concentration (TAC), the average chain length (ACL, following Poynter et al., 1989) and the odd over even predominance (OEP, following Hoefs et al. (2002), the latter being very similar to the carbon preference index (CPI), were calculated according to the Eqs. (4), (5) and (6), respectively. 


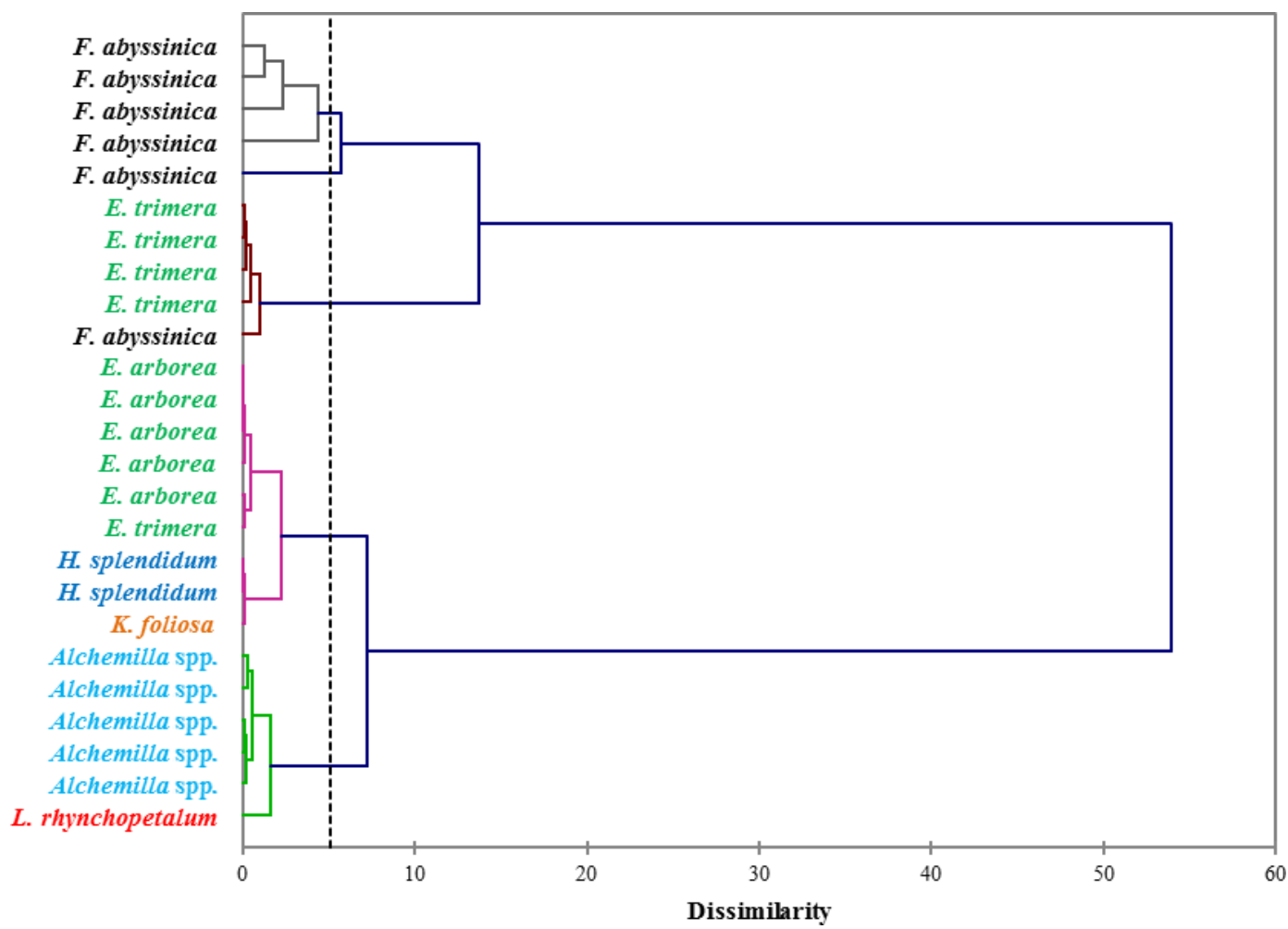

Figure 3. Dendrogram differentiating the dominant plant species of the Bale Mountains based on the concentrations of vanillyl, syringyl and cinnamyl lignin phenols ( $\mathrm{mg} \mathrm{g}^{-1}$ sample). The dotted vertical line represents the distance or dissimilarity between clusters.

TAC $=\Sigma \mathrm{C}_{n}$, with $n$ ranging from 25 to 35 ,

$\mathrm{ACL}=\Sigma\left(\mathrm{C}_{n} \times n\right) / \Sigma \mathrm{C}_{n}$,

where $n$ refers to the odd numbered $n$-alkanes ranging from 27 to 33

$\mathrm{OEP}=\left(\mathrm{C}_{27}+\mathrm{C}_{29}+\mathrm{C}_{31}+\mathrm{C}_{33}\right) /\left(\mathrm{C}_{26}+\mathrm{C}_{28}+\mathrm{C}_{30}+\mathrm{C}_{32}\right)$.

All calibrated datasets of the analytical results were subjected to simple correlation test and agglomerative hierarchical clustering (AHC) using XLSTAT (2014) statistical software. $\mathrm{R}$ software version 3.4.2 was also used to demonstrate taxonomic differences and the effect of biodegradation on the sample materials via ternary diagrams and notched box plots.

\section{Results and discussion}

\subsection{Lignin phenol concentration and patterns of contemporary vegetation}

The $\sum$ VSC of modern plants investigated from the two transects of the Bale Mountains ranges from 1.8 to $41.8 \mathrm{mg} \mathrm{g}^{-1}$, the sample with Festuca yielding the highest average contribution to TOC with up to $33 \mathrm{mg} \mathrm{g}^{-1}$ sample (Fig. 2). This is within the range reported in the literature (Belanger et al.,
2015; Hedges et al., 1986). Note that lignin phenol concentrations of grasses are higher compared to other vegetation of the Bale Mountains, although it is known that grasses contain only low amounts of lignin when compared to trees.

The concentrations of individual lignin phenols (vanillyl, syringyl and cinnamyl) allow us to chemotaxonomically differentiate the contemporary dominant plant species of the Bale Mountains. This is illustrated in Fig. 3, based on an agglomerative hierarchical cluster analysis (AHC). The abundance of individual lignin phenols (V, S and C) was specific to individual or restricted groups of plant and/or tissues applied to cluster different taxa (Belanger et al., 2015; Castañeda et al., 2009; Goñi and Hedges, 1992; Hedges and Mann, 1979; Tareq et al., 2004, 2006).

While Fig. 3 highlights the potential for chemotaxonomic differentiation of the investigated plants, it does not yet become clear from this hierarchical cluster analyses result which lignin phenols are characteristic for which plants and which lignin proxy might have potential for paleovegetation reconstructions. Therefore, Fig. 4 shows the relative abundance of $\mathrm{V}, \mathrm{S}$ and $\mathrm{C}$ for all investigated plant species in a ternary diagram. Accordingly, Erica arborea and Erica trimera are characterized by cinnamyl percentages of $>40 \%$, whereas, except for two Festuca samples, all other plants are characterized by cinnamyl percentages of $<40 \%$. Our results from fresh plant material are hence not in agree- 

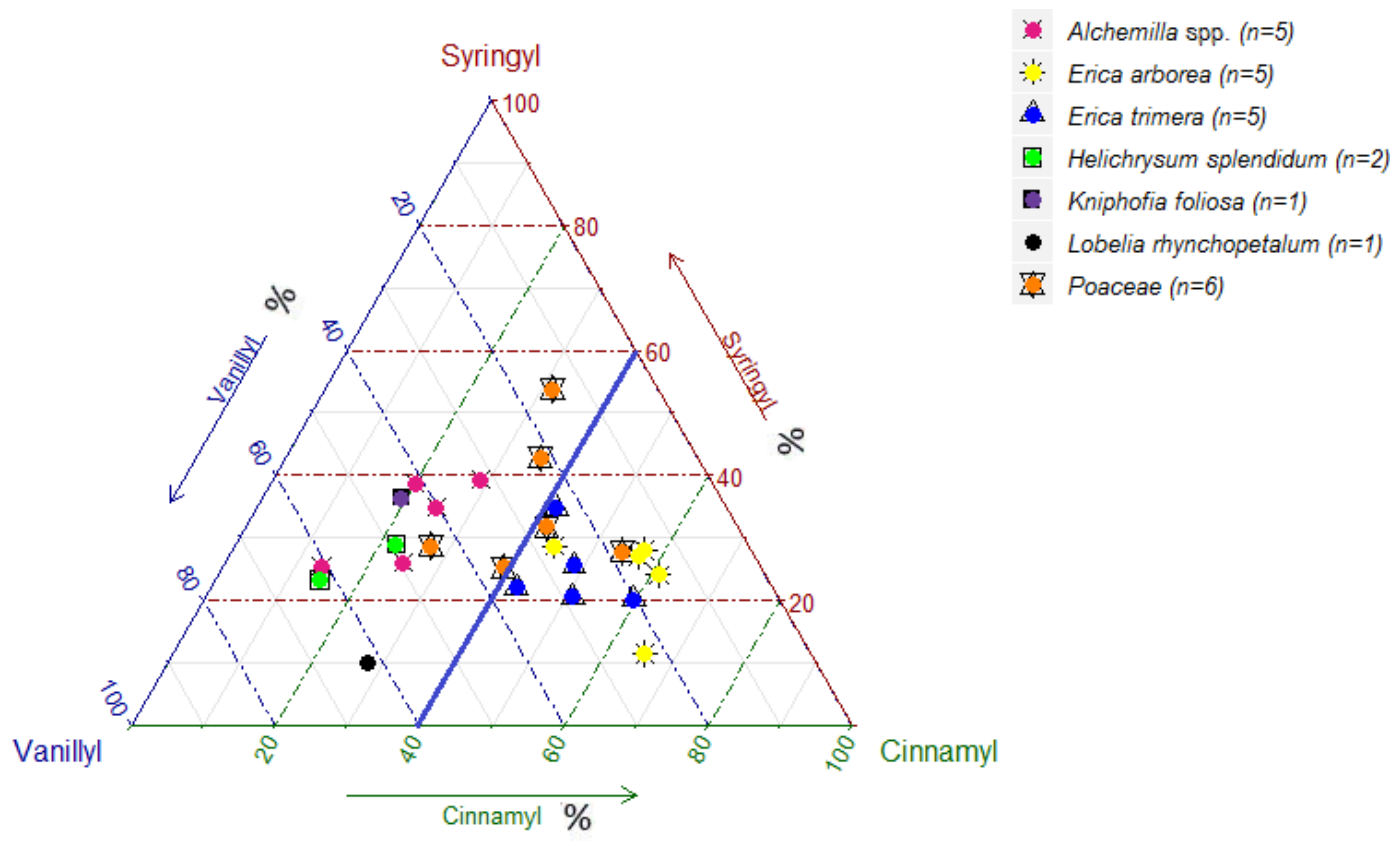

Figure 4. Ternary diagram for the relative abundances (\%) of vanillyl, syringyl and cinnamyl lignin phenols of the dominant vegetation. The blue line separates samples with more (right) versus less (left) than $40 \%$ cinnamyl.

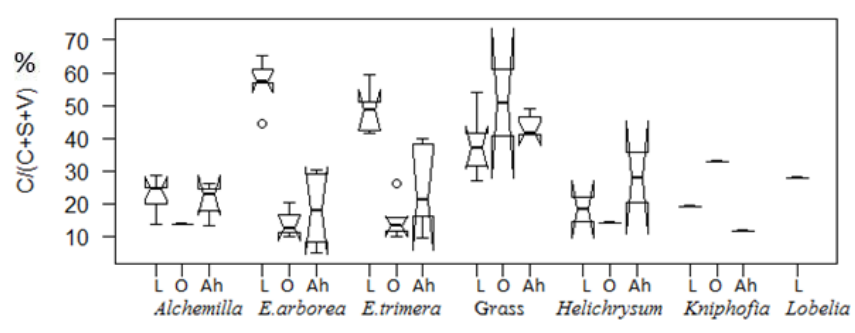

Figure 5. Box plot for the relative abundance of cinnamyl phenols (expressed as $\mathrm{C} /(\mathrm{V}+\mathrm{S}+\mathrm{C})$ in \%) in plants, O layers and $\mathrm{A}_{\mathrm{h}}$ horizons. The box plots indicate the median (solid line between the boxes) and interquartile range (IQR), with upper $(75 \%)$ and lower $(25 \%)$ quartiles and possible outliers (white circles). The notches display the confidence interval around the median within $\pm 1.57 \times \mathrm{IQR} /$ sqrt. Note that small sample sizes result in unidentifiable boxes (particularly Kniphofia and Lobelia).

ment with the finding of Hedges and Mann (1979) and Hedges et al. (1988) that high contributions of cinnamyl phenols are characteristic of non-woody grass and fern. Despite a relatively large scattering and a partial overlapping, our results suggest that the ratio $\mathrm{C} /(\mathrm{V}+\mathrm{S}+\mathrm{C})$ might be used as a proxy for distinguishing Erica spp. from other vegetation types of the Bale Mountains, with values $>0.40$ being generally characteristic for Erica spp.

\subsection{Lignin phenol patterns of $\mathrm{O}$ layers and $A_{h}$ horizons}

$\sum$ VSC strongly decreases from plants over $\mathrm{O}$ layers to $\mathrm{A}_{\mathrm{h}}$ horizons, except for Helichrysium, which yielded the lowest $\sum$ VSC values of all plants (Fig. 2). This descending trend is in agreement with the literature (Amelung et al., 1997; Belanger et al., 2015) and reflects the preferential degradation of the plant-derived lignin phenols compared to other soil organic matter constituents. At the same time, the input of root-derived lignin is very likely. As a result of both processes, i.e., degradation and lignin input by roots and the large and chemotaxonomically characteristic contribution of $\mathrm{C}$ in Erica plant material $(\geq 41.5 \%)$ is lost in the O layers $(\mathrm{C}<27 \%)$, whereas the two investigated $\mathrm{O}$ layers under Festuca yielded relative C contributions $>40 \%$. Similarly, $\mathrm{A}_{\mathrm{h}}$ horizons under Festuca are characterized by $\mathrm{C}$ contributions $>40 \%$, while all $\mathrm{A}_{\mathrm{h}}$ horizons that developed under other vegetation types are characterized by $\mathrm{C}$ contributions $<40 \%$. This finding does not ad hoc preclude the above proposed lignin phenol proxy $\mathrm{C} /(\mathrm{V}+\mathrm{S}+\mathrm{C})$ for reconstructing vegetation history, but it definitely challenges its application. Degradation and lignin input by roots need to be considered when interpreting phenol proxies. This is relevant beyond our case study concerning Erica versus Festuca and Helichrysum (Fig. 5) and is likely more relevant in paleosols than in sedimentary archives.

In our study, we found no consistent increase and systematic relationship between $\mathrm{Ac} / \mathrm{Al}$ ratios of $\mathrm{V}$ and $\mathrm{S}$, which are used as degradation proxies in some studies (Amelung et al., 2002; Hedges and Ertel, 1982; Möller et al., 2002; Tareq 


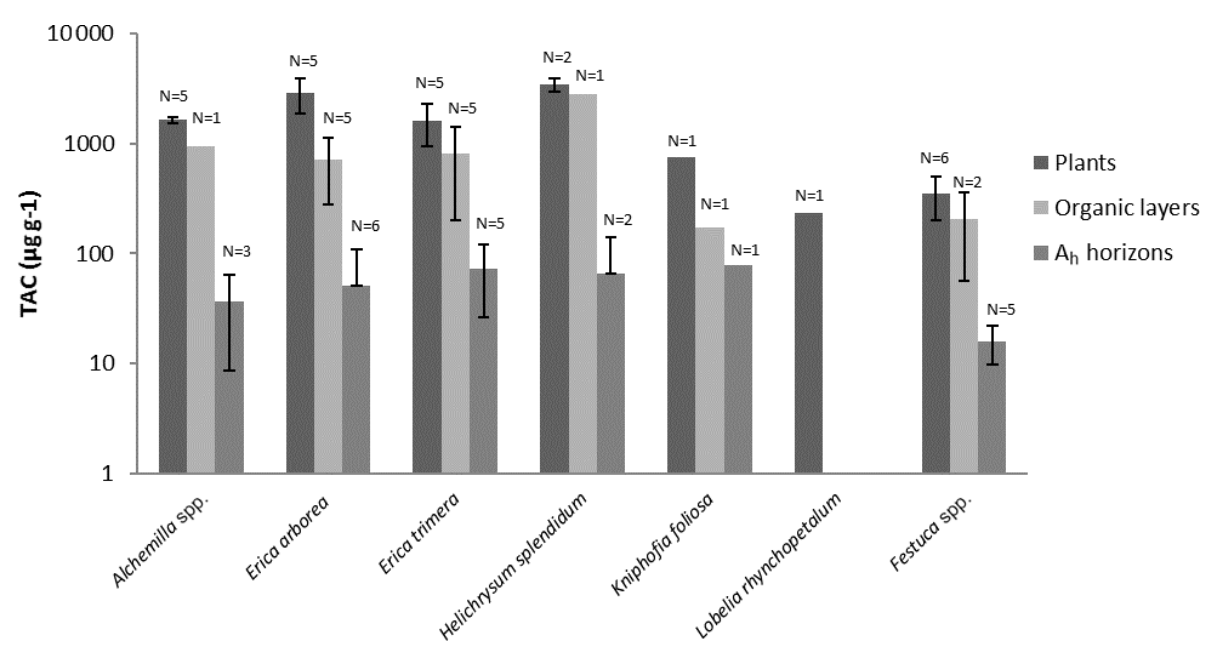

Figure 6. Total long-chain $n$-alkane concentrations (TACs) of plants, O layers and $\mathrm{A}_{\mathrm{h}}$ horizons. Error bars illustrate standard deviations.
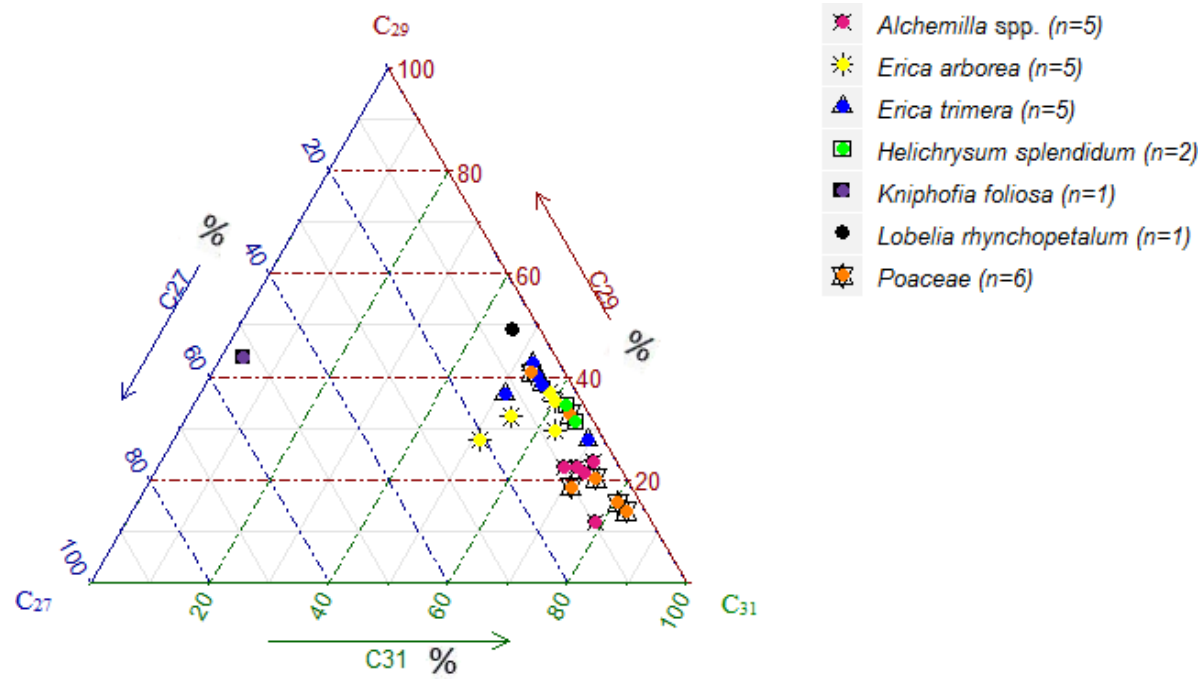

Figure 7. Ternary diagram illustrating the relative abundance (\%) of the $n$-alkanes $C_{27}, C_{29}$ and $C_{31}$ in the investigated plant samples.

et al., 2011), and source proxy (S / V). This is in agreement with other studies (Belanger et al., 2015), and we therefore suggest that caution needs to be taken when using $\mathrm{Ac} / \mathrm{Al}$ ratios as degradation proxies.

\section{3 n-alkane concentrations and patterns of contemporary plants}

To characterize the dominant plant species chemotaxonomically, $n$-alkanes with a chain length of 21-37 C atoms were considered as characteristic for epicuticular leaf waxes, typical for higher plants (Eglinton and Hamilton, 1967; Hoffmann et al., 2013). Most of the investigated plant species showed total $n$-alkane concentrations (TAC, $\mathrm{C}_{25}-\mathrm{C}_{35}$ ) above $800 \mathrm{\mu g} \mathrm{g}^{-1}$. Only Lobelia and Festuca exhibited total $n$ alkane concentrations below $800 \mu^{-1} g^{-1}$ (Fig. 6). The TAC values of the $\mathrm{O}$ layers were only slightly lower when com- pared to contemporary plants. By contrast, the TAC values of the $A_{h}$ horizons were significantly lower compared to contemporary plants (Fig. 6). The $n$-alkane concentrations in this study are in agreement with research findings for fresh plant materials (Bush and McInerney, 2013; Feakins et al., 2016) and soils (Schäfer et al., 2016).

Contrary to lignin phenols, hierarchical cluster analysis of individual $n$-alkanes did not allow for unambiguous differentiation between Erica and non-Erica species. Therefore, the $n$-alkane patterns do not allow for developing a proxy for identifying Erica, at least in the Bale Mountains. Average chain length values (ACLs) of plant and soil $n$-alkanes range between 28 to 32 and 29 to 31 , respectively. The ACLs of Erica arborea (30.5) and Erica trimera (30.5) are identical, which could be explained by the monophyletic origin of the species (Guo et al., 2014). Grass sam- 


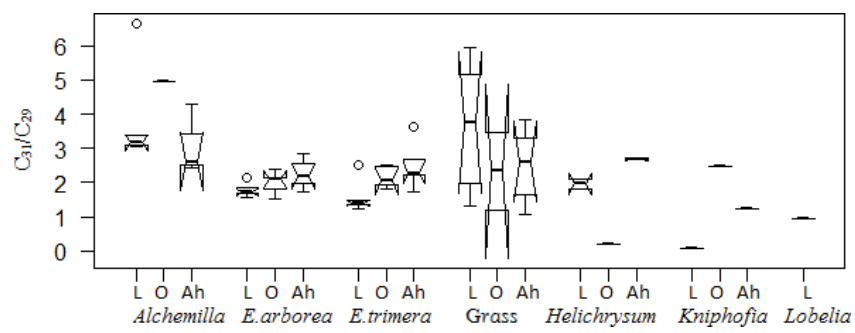

Figure 8. Box plot for the ratio $\mathrm{C}_{31} / \mathrm{C}_{29}$ in plant samples, organic layers and $A_{h}$ horizons. The box plots indicate the median (solid line between the boxes) and interquartile range (IQR), with upper $(75 \%)$ and lower $(25 \%)$ quartiles and possible outliers (white circles). The notches display the confidence interval around the median within $\pm 1.57 \times \mathrm{IQR} /$ sqrt. Note that small sample sizes result in unidentifiable boxes (particularly Kniphofia and Lobelia).

ples (Festuca abyssinica) exhibited a clear predominance of $\mathrm{C}_{31}$ (Fig. 7), which was reported before by different authors (Schäfer et al., 2016; Zech, 2009). Most other investigated plant species revealed a predominance of either $\mathrm{C}_{29}$ or $\mathrm{C}_{31}$. Only Kniphofia foliosa is characterized by high relative abundance of $\mathrm{C}_{27}$ and $\mathrm{C}_{29}$, while $\mathrm{C}_{31}$ is almost absent (Fig. 7).

Apart from individual $n$-alkanes, the ratio of $\mathrm{C}_{31} / \mathrm{C}_{29}$ depicts Erica litter as significantly distinguishable from the other species, except for Helichrysum splendidum (Fig. 8).

\section{$3.4 n$-alkane concentration and pattern of $\mathrm{O}$ layers and $A_{h}$ horizons}

The TAC values decrease in the following order: plants $>\mathrm{O}$ layers $>\mathrm{A}_{\mathrm{h}}$ horizon (Fig. 6). The odd over even predominance values (OEPs) of the plants, $\mathrm{O}$ layers and $A_{h}$ horizons range from 5 to $90(\bar{x}=21), 4$ to 42 $(\bar{x}=15)$ and 2 to $37(\bar{x}=16)$, respectively. The OEP values of the plants (which are almost identical to the CPI values) are therefore well within the range reported (Diefendorf et al., 2011) for angiosperms. Decreasing OEP values towards $\mathrm{O}$ layers and $\mathrm{A}_{\mathrm{h}}$ horizons are often observed and can be explained with organic matter degradation (Schäfer et al., 2016; Zech et al., 2011b). The still relatively high OEP values $(\bar{x}=16)$ obtained for the topsoils of our study area indicate that the $n$-alkanes are not strongly degraded. Importantly, $n$-alkane degradation affects not only the OEP values but also the $n$-alkane ratios, such as the above presented ratio $\mathrm{C}_{31} / \mathrm{C}_{29}$ that allows distinguishing Erica from non-Erica vegetation. As a result, this ratio in particular no longer allows for chemotaxonomically distinguishing between soils that have developed under Erica versus Alchemilla and grass (Fig. 8). Unlike with lignin phenols, a noteworthy influence from root-derived $n$-alkanes on $\mathrm{O}$ layers and $\mathrm{A}_{\mathrm{h}}$ horizons can be excluded. This is based on the notion that roots contain lower $n$-alkane concentrations by several magnitudes than above-ground plant material and results from studies using
${ }^{14} \mathrm{C}$ dating of $n$-alkanes in loess-paleosol sequences (Häggi et al., 2014; Zech et al., 2017).

\section{Conclusions and implications for paleovegetation} reconstructions in the Bale Mountains

One of the premises within the Mountain Exile Hypothesis project (DFG-FOR 2358) is to reconstruct the dynamics of Erica vegetation on the Sanetti Plateau in the Bale Mountains National Park, Ethiopia. While our companion paper by Mekonnen et al. (2019) focused on stable carbon and nitrogen isotopes and hemicellulose-derived sugar biomarkers, we tested in this regional calibration study the potential of cupric oxide lignin phenols and leaf-wax-derived $n$-alkanes to serve as unambiguous proxies for differentiating between Erica versus non-Erica vegetation.

A hierarchical cluster analysis of individual lignin phenols was promising and allowed the chemotaxonomic differentiation of Erica from non-Erica vegetation based on relatively high relative contribution of cinnamyl ( $\geq 40 \%$ ) phenols. However, this characteristic pattern is not reflected in the $\mathrm{O}$ layers and $\mathrm{A}_{\mathrm{h}}$ horizons. In all likelihood, the loss of the cinnamyl dominance is caused by preferential degradation. Unlike expected, we found no overall evidence for increasing $(\mathrm{Ac} / \mathrm{Al})_{\mathrm{V}+\mathrm{S}}$ ratios as a proxy for degradation from plant material over $\mathrm{O}$ layers to $\mathrm{A}_{\mathrm{h}}$ horizons.

Erica could not be differentiated chemotaxonomically from all other investigated plant species using $n$-alkanes in a hierarchical cluster analysis. Nevertheless, Erica was still characterized in our dataset by significantly lower $\mathrm{C}_{31} / \mathrm{C}_{29}$ ratios compared to Alchemilla and grasses. However, like lignin-derived phenol proxies, the $n$-alkane patterns are changing due to degradation from plant material over $\mathrm{O}$ layers to $A_{h}$ horizons, thus inhibiting their application for an unambiguous chemotaxonomic identification of Erica in soils and sediments. Therefore, future work is planned focusing on alternative molecular markers such as tannin-derived phenols and terpenoids.

Data availability. The underlying datasets used in this study are accessible via https://doi.org/10.5281/zenodo.3372104.

Author contributions. BG, WZ and MZ developed the project idea in collaboration with SN and TB. WZ, BL and BM designed and handled field research work. BL and LB performed the laboratory work. The manuscript was prepared by BL with the support of $\mathrm{MZ}$ and the other co-authors.

Competing interests. The authors declare that they have no conflict of interest. 
Acknowledgements. We are grateful to the Ethiopian Biodiversity Institute, Ethiopian Wildlife Conservation Authority, Bale Mountains National Park and Addis Ababa University for providing us with access to the plant genetic resources, access to the Bale Mountains National Park and for their scientific collaboration, respectively. We acknowledge the financial support within the funding program Open Access Publishing by the German Research Foundation (DFG). Bruk Lemma expresses his gratitude to the Catholic Academic Exchange Services (KAAD, Germany) for the $\mathrm{PhD}$ scholarship and his sincere thanks to Heike Maennicke for kind assistance during the laboratory work. We kindly thank three anonymous reviewers for their constructive comments and suggestions that helped us to improve the quality of this paper.

Financial support. This research has been supported by the DFG within Research Unit "The Mountain Exile Hypothesis" (grant nos. GL 327/18-1, ZE 844/10-1 and ZE 154/70-1).

\section{References}

Amelung, W., Zech, W., and Flach, K. W.: Climatic effects on soil organic matter composition in the Great Plains, Soil Sci. Soc. Am. J., 61, 115-123, 1997.

Amelung, W., Martius, C., Bandeira, A. G., Garcia, M. V., and Zech, W.: Lignin characteristics and density fractions of termite nests in an Amazonian rain forest-indicators of termite feeding guilds, Soil Biol. Biochem., 34, 367-372, 2002.

Belanger, E., Lucotte, M., Gregoire, B., Moingt, M., Paquet, S., Davidson, R., Mertens, F., Passos, C. J. S., and Romana, C.: Lignin signatures of vegetation and soils in tropical environments, Adv. Enviro. Res., 4, 247-262, 2015.

Billi, P.: Geomorphological landscapes of Ethiopia, in: Landscapes and landforms of Ethiopia, edited by: Billi, P., Springer, Dordrecht, Netherlands, 3-32, 2015.

Bonnefille, R. and Hamilton, A.: Quaternary and late Tertiary history of Ethiopian vegetation, Symb. Bot. Ups, 26, 48-63, 1986.

Bonnefille, R. and Mohammed, U.: Pollen-inferred climatic fluctuations in Ethiopia during the last 3000 years, Palaeogeogr. Palaeocl., 109, 331-343, 1994.

Bush, R. T. and McInerney, F. A.: Leaf wax n-alkane distributions in and across modern plants: implications for paleoecology and chemotaxonomy, Geochim. Cosmochim. Ac., 117, 161-179, 2013.

Castañeda, I. S., Werne, J. P., Johnson, T. C., and Filley, T. R.: Late Quaternary vegetation history of southeast Africa: the molecular isotopic record from Lake Malawi, Palaeogeogr. Palaeocl., 275, 100-112, 2009.

Diefendorf, A. F., Freeman, K. H., Wing, S. L., and Graham, H. V.: Production of $n$-alkyl lipids in living plants and implications for the geologic past, Geochim. Cosmochim. Ac., 75, 7472-7485, 2011.

Eglinton, G. and Hamilton, R. J.: Leaf epicuticular waxes, Science, 156, 1322-1335, 1967.

Eglinton, T. I. and Eglinton, G.: Molecular proxies for paleoclimatology, Earth Planet. Sc. Lett., 275, 1-16, 2008.

Ertel, J. R. and Hedges, J. I.: The lignin component of humic substances: distribution among soil and sedimentary humic, ful- vic, and base-insoluble fractions, Geochim. Cosmochim. Ac., 48, 2065-2074, 1984.

Feakins, S. J., Peters, T., Wu, M. S., Shenkin, A., Salinas, N., Girardin, C. A., Bentley, L. P., Blonder, B., Enquist, B. J., and Martin, R. E.: Production of leaf wax $n$-alkanes across a tropical forest elevation transect, Org. Geochem., 100, 89-100, 2016.

Friis, I.: Zonation of Forest Vegetation on the South Slope of Bale Mountains, South Ethiopia, Sinet-an Ethiopian Journal of Science, 29-44, 1986.

Glaser, B. and Zech, W.: Reconstruction of climate and landscape changes in a high mountain lake catchment in the Gorkha Himal, Nepal during the Late Glacial and Holocene as deduced from radiocarbon and compound-specific stable isotope analysis of terrestrial, aquatic and microbial biomarkers, Org. Geochem., 36, 1086-1098, 2005.

Goñi, M. A. and Hedges, J. I.: Lignin dimers: Structures, distribution, and potential geochemical applications, Geochim. Cosmochim. Ac., 56, 4025-4043, 1992.

Guo, N., Gao, J., He, Y., Zhang, Z. and Guo, Y.: Variations in leaf epicuticular $n$-alkanes in some Broussonetia, Ficus and Humulus species, Biochem. Syst. Ecol., 54, 150-156, 2014.

Häggi, C., Zech, R., McIntyre, C., Zech, M., and Eglinton, T. I.: On the stratigraphic integrity of leaf-wax biomarkers in loess paleosols, Biogeosciences, 11, 2455-2463, https://doi.org/10.5194/bg-11-2455-2014, 2014.

Hamilton, A. C.: Environmental history of East Africa: a study of the Quaternary, Academic Press, London, UK, 328 pp., 1982.

Hedberg, O.: Features of afroalpine plant ecology, Swedish Science Press, Uppsala, Sweden, 148 pp., 1964.

Hedges, J. I. and Ertel, J. R.: Characterization of lignin by gas capillary chromatography of cupric oxide oxidation products, Anal. Chem., 54, 174-178, 1982.

Hedges, J. I. and Mann, D. C.: The characterization of plant tissues by their lignin oxidation products, Geochim. Cosmochim. Ac., 43, 1803-1807, 1979.

Hedges, J. I., Clark, W. A., Quay, P. D., Richey, J. E., Devol, A. H., and Santos, M.: Compositions and fluxes of particulate organic material in the Amazon River1, Limnol. Oceanogr., 31, 717-738, 1986.

Hedges, J. I., Blanchette, R. A., Weliky, K., and Devol, A. H.: Effects of fungal degradation on the $\mathrm{CuO}$ oxidation products of lignin: a controlled laboratory study, Geochim. Cosmochim. Ac., 52, 2717-2726, 1988.

Hicks, S.: When no pollen does not mean no trees, Veg. Hist. Archaeobot., 15, 253-261, 2006.

Hillman, J. C.: Conservation in Bale mountains national park, Ethiopia, Oryx, 20, 89-94, 1986.

Hillman, J. C.: The Bale Mountains National Park area, southeast Ethiopia, and its management, Mountain Research and Development, 253-258, 1988.

Hoefs, M. J., Rijpstra, W. I. C., and Damsté, J. S. S.: The influence of oxic degradation on the sedimentary biomarker record I: Evidence from Madeira Abyssal Plain turbidites, Geochim. Cosmochim. Ac., 66, 2719-2735, 2002.

Hoffmann, B., Kahmen, A., Cernusak, L. A., Arndt, S. K., and Sachse, D.: Abundance and distribution of leaf wax $n$-alkanes in leaves of Acacia and Eucalyptus trees along a strong humidity gradient in northern Australia, Org. Geochem., 62, 62-67, 2013. 
Jansen, B., van Loon, E. E., Hooghiemstra, H., and Verstraten, J. M.: Improved reconstruction of palaeo-environments through unravelling of preserved vegetation biomarker patterns, Palaeogeogr. Palaeocl., 285, 119-130, 2010.

Kidane, Y., Stahlmann, R., and Beierkuhnlein, C.: Vegetation dynamics, and land use and land cover change in the Bale Mountains, Ethiopia, Environ. Monit. Assess., 184, 7473-7489, 2012.

Koch, K., Bhushan, B., and Barthlott, W.: Multifunctional surface structures of plants: an inspiration for biomimetics, Prog. Mater. Sci., 54, 137-178, 2009.

Kolattukudy, P. E.: Plant waxes, Lipids, 5, 259-275, 1970.

Maffei, M.: Chemotaxonomic significance of leaf wax alkanes in the Gramineae, Biochem. Syst. Ecol., 24, 53-64, 1996.

Maffei, M., Badino, S., and Bossi, S.: Chemotaxonomic significance of leaf wax $n$-alkanes in the Pinales (Coniferales), J. Biol. Res., 1, 3-19, 2004.

Mekonnen, B., Zech, W., Glaser, B., Lemma, B., Bromm, T., Nemomissa, S., Bekele, T., and Zech, M.: Chemotaxonomic patterns of vegetation and soils along altitudinal transects of the Bale Mountains, Ethiopia, and implications for paleovegetation reconstructions - Part 1: stable isotopes and sugar biomarkers, E\&G Quaternary Sci. J., 69, 177-188, https://doi.org/10.5194/egqsj69-177-2019, 2019.

Miehe, S. and Miehe, G.: Ericaceous forest and heath land in Bale Mountains of South Ethiopia, Ecology and Man's Impact, Hamburg, Stiftung Walderhaltung in Africa Hamburg, Germany, 1994.

Möller, A., Kaiser, K., and Zech, W.: Lignin, carbohydrate, and amino sugar distribution and transformation in the tropical highland soils of northern Thailand under cabbage cultivation, Pinus reforestation, secondary forest, and primary forest, Soil Res., 40, 977-998, 2002.

Ortu, E., Brewer, S., and Peyron, O.: Pollen-inferred palaeoclimate reconstructions in mountain areas: problems and perspectives, $\mathrm{J}$. Quaternary Sci., 21, 615-627, 2006.

Osmaston, H. A., Mitchell, W. A., and Osmaston, J. N.: Quaternary glaciation of the Bale Mountains, Ethiopia, J. Quaternary Sci., 20, 593-606, 2005.

Poynter, J. G., Farrimond, P., Robinson, N., and Eglinton, G.: Aeolian-derived higher plant lipids in the marine sedimentary record: Links with palaeoclimate, in Paleoclimatology and paleometeorology: modern and past patterns of global atmospheric transport, Springer, 435-462, 1989.

Rommerskirchen, F., Plader, A., Eglinton, G., Chikaraishi, Y., and Rullkötter, J.: Chemotaxonomic significance of distribution and stable carbon isotopic composition of long-chain alkanes and alkan-1-ols in $\mathrm{C}_{4}$ grass waxes, Org. Geochem., 37, 1303-1332, 2006

Schäfer, I. K., Lanny, V., Franke, J., Eglinton, T. I., Zech, M., Vysloužilová, B., and Zech, R.: Leaf waxes in litter and topsoils along a European transect, Soil, 2, 551-564, 2016.

Street-Perrott, F. A., Ficken, K. J., Huang, Y. and Eglinton, G.: Late Quaternary changes in carbon cycling on Mt. Kenya, East Africa: an overview of the $\delta 13 \mathrm{C}$ record in lacustrine organic matter, Quaternary Sci. Rev., 23, 861-879, 2004.

Tareq, S. M., Tanaka, N., and Ohta, K.: Biomarker signature in tropical wetland: lignin phenol vegetation index (LPVI) and its implications for reconstructing the paleoenvironment, Sci. Tot. Environ., 324, 91-103, 2004.
Tareq, S. M., Handa, N., and Tanoue, E.: A lignin phenol proxy record of mid Holocene paleovegetation changes at Lake DaBuSu, northeast China, J. Geochem. Explor., 88, 445-449, 2006.

Tareq, S. M., Kitagawa, H., and Ohta, K.: Lignin biomarker and isotopic records of paleovegetation and climate changes from Lake Erhai, southwest China, since 18.5 ka BP, Quatern. Int., 229, 4756, 2011.

Thevenot, M., Dignac, M.-F., and Rumpel, C.: Fate of lignins in soils: a review, Soil Biol. Biochem., 42, 1200-1211, 2010.

Tiercelin, J.-J., Gibert, E., Umer, M., Bonnefille, R., Disnar, J.R., Lézine, A.-M., Hureau-Mazaudier, D., Travi, Y., Kéravis, D., and Lamb, H. F.: High-resolution sedimentary record of the last deglaciation from a high-altitude lake in Ethiopia, Quaternary Sci. Rev., 27, 449-467, 2008.

Umer, M., Kebede, S., and Osmaston, H.: Quaternary glacial activity on the Ethiopian Mountains, Developments in Quaternary Sciences, 2, 171-174, 2004.

Umer, M., Lamb, H. F., Bonnefille, R., Lézine, A.-M., Tiercelin, J.-J., Gibert, E., Cazet, J.-P., and Watrin, J.: Late pleistocene and holocene vegetation history of the bale mountains, Ethiopia, Quaternary Sci. Rev., 26, 2229-2246, 2007.

Woldu, Z., Feoli, E., and Nigatu, L.: Partitioning an elevation gradient of vegetation from Southeastern Ethiopia by probabilistic methods, Plateau, 81, 189-198, 1989.

Yimer, F., Ledin, S., and Abdelkadir, A.: Soil organic carbon and total nitrogen stocks as affected by topographic aspect and vegetation in the Bale Mountains, Ethiopia, Geoderma, 135, 335-344, 2006.

Zech, M.: Evidence for Late Pleistocene climate changes from buried soils on the southern slopes of Mt. Kilimanjaro, Tanzania, Palaeogeogr. Palaeocl., 242, 303-312, 2006.

Zech, M.: Reconstructing Quaternary vegetation history in the Carpathian Basin, SE Europe, using $n$-alkane biomarkers as molecular fossils: problems and possible solutions, potential and limitations, E\&G Quaternary Sci. J., 58, 148-155, 2009.

Zech, M. and Glaser, B.: Improved compound-specific $\delta 13 \mathrm{C}$ analysis of $n$-alkanes for application in palaeoenvironmental studies, Rapid Commun. Mass Sp., 22, 135-142, 2008.

Zech, M., Pedentchouk, N., Buggle, B., Leiber, K., Kalbitz, K., Marković, S. B., and Glaser, B.: Effect of leaf litter degradation and seasonality on $\mathrm{D} / \mathrm{H}$ isotope ratios of n-alkane biomarkers, Geochim. Cosmochim. Ac., 75, 4917-4928, 2011a.

Zech, M., Leiber, K., Zech, W., Poetsch, T., and Hemp, A.: Late Quaternary soil genesis and vegetation history on the northern slopes of Mt. Kilimanjaro, East Africa, Quaternary Int., 243, 327-336, 2011b.

Zech, M., Zech, R., Buggle, B., and Zöller, L.: Novel methodological approaches in loess research - interrogating biomarkers and compound-specific stable isotopes, E\&G Quaternary Sci. J., 60, 13, https://doi.org/10.3285/eg.60.1.12, 2011c.

Zech, M., Krause, T., Meszner, S., and Faust, D.: Incorrect when uncorrected: reconstructing vegetation history using $n$-alkane biomarkers in loess-paleosol sequences - a case study from the Saxonian loess region, Germany, Quaternary Int., 296, 108-116, 2013. 
Zech, M., Kreutzer, S., Zech, R., Goslar, T., Meszner, S., McIntyre, C., Häggi, C., Eglinton, T., Faust, D., and Fuchs, M.: Comparative ${ }^{14} \mathrm{C}$ and OSL dating of loess-paleosol sequences to evaluate post-depositional contamination of $n$-alkane biomarkers, Quaternary Res., 87, 180-189, 2017.
Ziegler, F., Kögel, I. and Zech, W.: Alteration of gymnosperm and angiosperm lignin during decomposition in forest humus layers, Z. Planz. Bodenkunde, 149, 323-331, 1986. 